\title{
The Integration of University with High School through An Experience Using Project Led Education
}

\author{
Luciano de Azedias Marins* \\ *Departamento da Área de Exatas e Engenharias, Centro Universitário de Volta Redonda, \\ Volta Redonda, Brazil. \\ E-mail: Luciano.marins@foa.org.br \\ Edson de Paula Carvalho \\ •Coordenadoria de Engenharia Elétrica, Centro Universitário de Volta Redonda, \\ Volta Redonda, Brazil \\ E-mail: edson.carvalho@foa.org.br \\ Walkiria Silva Soares Marins \\ •Centro Universitário de Volta Redonda, Volta Redonda, Brazil. \\ E-mail: walkiriamarins@hotmail.com \\ Douglas do Couto Soares \\ 'Ciep 291 Dom Martinho Schlude, Pinheiral, Brasil. \\ E-mail: soares.doug@hotmail.com \\ Francilaine Calixto Gouveia ${ }^{\circ}$ \\ ${ }^{\circ}$ Ciep 291 Dom Martinho Schlude, Pinheiral, Brasil. \\ E-mail: franci.calixto@hotmail.com
}




\begin{abstract}
The present work describes an exchange of experiences among students of the Escola Estadual CIEP 291 - Dom Martinho Schlude in the city of Pinheiral, RJ, with the Advertising and Propaganda students, Information Systems and Engineering of the Centro Universitário de Volta Redonda (UniFOA) during a period of six months. The partnership arose due to a school's need to develop some actions to participate in the Jaguar Land Rover Competition, $4 \mathrm{x} 4$ in Schools Technology Challenge. The challenge required technological changes in a prototype of a $4 \times 4$ vehicle, with approximately $20 \mathrm{~cm}$ long, $10 \mathrm{~cm}$ wide and $10 \mathrm{~cm}$ high. A micro-enterprise was created, with a logo and marketing actions, approaching an entrepreneurial vision. All actions taken were on display, on a given day, through verbal presentations and visualization of the team's booth. In addition to fulfill these needs, each team were evaluated on the performance test of the prototype in an obstacle course to take time. A partnership with UniFOA was created to assist in project development and support in the area of Technology, Strategy and Marketing. Companhia Siderúrgica Nacional (CSN) led the industry's support in research and development for strategic planning for the team's actions. The students of the courses of Design, Information Systems, Advertising and Marketing and Electrical and Mechanical Engineering assigned two hours a week for approximately six months to a technical monitoring involving the needs of the Team. In the end, the secondary students were able to elaborate all the necessary requirements according to the regulation, participating in the National Stage and later of the World Stage. The UniFOA students were able to apply the concepts using Project Based Learning as a methodology, fulfilling the role of the University in the Society that is to produce knowledge, generate critical thinking, organize and articulate knowledge, forming citizens and professionals. The experience was very enriching, providing for all involved strengthening of numerous cognitive and socio emotional skills. As a result of the project, the AUTO291 Team was the champion in the National Stage, conquering the opportunity to represent the country in the world event, being the champion team in the category of "Best Media Dissemination" and was among the top three in Abu Dhabi, United Arab Emirates.
\end{abstract}

Keywords: Basic Education, Entrepreneurship, Higher Education, Interdisciplinary, Socialemotional Skills.

\title{
1. Introduction
}

Post modernity brought with it the sharp growth of technology. At all times we are bombarded by new knowledge. Virtual, cybernetic stimuli required a paradigm shift for man. The construction of knowledge permeates the constant cultural becoming in which we are immersed. Education, teaching and learning could not be placed at the margin of these transformations. More than an ideological discourse on learning theories, we are invited to a new model of construction that is appropriate to the new times. The guiding question should be established on what attributes are necessary to the subjects we are forming. Luckesi (1994), who is a great philosopher of education, points out that there are three philosophical trends in the interpretation of education: The redemptive tendency proposes an optimistic pedagogical action from the political point of view, believing that education has almost absolute powers over Society. The reproductive tendency is critical in relation to the understanding of education in Society, but pessimistic, seeing no way out of it, except to submit to its determinants. Lastly, the transformative tendency, which is critical, refuses both to illusory optimism and to immobilizing pessimism. Therefore, it is proposed to understand education within its constraints and to act strategically for its transformation ${ }^{1}$. Seeking this latest trend, which meets the needs impressed by a postmodern Society which we live, the 
question that must be raised certainly is: What form must knowledge be conceived in? The same author above, in the same work, shows us that "knowledge must be a way of existing and seeing the world on the part of every citizen. And to do so, one must appropriate knowledge in an existential way. It should become part of the life of every human being [...] To gain a new meaning, knowledge assimilated by the student must be something; significant and existential"1. Vygotsky proposes, according to the historical-cultural theory, that "the individual is constituted as such not only due to the processes of organic maturation, but, mainly, through their social interactions, from the exchanges established with their peers. Human psychic functions are intimately linked to learning, to the appropriation (through language) of the cultural legacy of their group [...] But for its appropriation there must also be internalization, which implies the transformation of external processes (concretized in the activities), in an intrapsychological process (where the activity is reconstructed internally). The long path of human development therefore follows the direction of the social into the individual". We can observe that "historical-cultural theory brings in its body extremely direct relations to the teaching-learning process, addressing the importance of interaction, of sociability in knowledge's construction. This interaction happens in the social environment, in the school as a space for the construction and development of the subject, a place where the student must be seen in its globality, respecting their affective, cognitive and psychomotor dimensions [...] Thus, affectivity is a component of intelligence, that is, smart activity supposes affective experiences and vice-versa" ${ }^{\prime 3}$.

Starting from the perspective of this pedagogical vision, where knowledge presupposes an interactive, meaningful, critical and social praxis, we find methodologies that approach this conception "as a result of this journey towards education, in 1930, led by Anisio Teixeira, the movement of New School emerges, which has brought new directions for education regarding the schools vision for all in order to combat social inequalities. With the Progressive Tendency that gives pedagogy new atmospheres to guide school destinations, the school is revolutionized and becomes a revolution, as it is designed to suit the individual needs. Gradually delineating the conception of a school that has the student as the center and subject of the learning process. The contents begin to be worked in a practical, experiential way, the inquiry is to have access to the knowledge. This methodology makes the student participant in their learning process and instigates the search for answers to their questions and therefore making possible the construction"4.

With the emergence of the New School, the intrinsic relationships of learning; process were changing the position of its actors in the scenario "it is worth mentioning that in the methodological construction of the New School, the activity and interest of the apprentice were valued, not those of the teacher. Thus, Dewey, through his ideology of the New School, had great influence in this idea when he defended that the learning occurs by the action, placing the student in the center of the processes of teaching and learning. From this point of view, the fragmentation of contents and their disarticulation with the social context, a fact that evidences the historical dichotomy between theory and practice, can be one of the causes of students lack of motivation, lack of interest and apathy. This is why it is defended the idea that the education developed in the school must be useful for life, so that students can articulate the knowledge built with real possibilities of practical application, that is, learning meaningfully, with contextualized meaning" .

Paulo Freire (1996) says that "educational work needs to be based on reality, in order to allow permanent dialogue with reflection in a process of knowledge formulation, supported by a theory-practice relationship ${ }^{\prime 6}$.

Apprenticeship emerges from reality and its reflection on it as Freire asserts, preparing the subject for life as Dewey states it. When we look at the vision of this last author, we realize the background of Dewey's educational perspective is the preparation for life therefore, the constant concern for the student's professional and intellectual ${ }^{7}$.

In order to prepare the learner for life we must first draw a north where we understand 
that teaching and learning is not a watertight thing, given in itself, but it is the result of a process. "This process, which is linked to students intellectual development in the school context, turns to the formation of concepts, a process marked by three stages: first, syncretic heaps; the second, thought by complexes, and the third, thought by concepts".8.

When we set out to carry out this activity "thinking Didactics as a process, exercise, reality in constitution mobilizes us towards the challenges of concrete reality, which slip into uncertainties and curiosities, arising from the actions and relationships experienced in the classroom"9.

In these relationships established "school knowledge is potentially a promoter of areas of proximal development, as it creates learning obstacles for individual pupils, who, when relying on the intervention of the teacher or other colleagues, may later overcome them".8.

For Vygotsky Zone of proximal development is the distance between the current, level of development, determined by the ability to solve a problem individually, and the level of potential development, determined by the ability to solve a E under the guidance of an adult or in collaboration with a more capable colleague ${ }^{10}$.

Thus, "it is fundamental that the teacher participates in the process of rethinking the construction of knowledge, in which mediation and interaction are the essential presuppositions for learning"11.

The path to be taken in the arid achievement of this objective concerns the intrinsic search for a methodology that meets this new configuration of subjects that we want to form. But rather than forms of subjectivation, we pass through the epistemology of our own knowledge to embark on the search for teaching methodology that proposes to meet this new entity that emerges in postmodernity. The active methodology brings us a discourse that appropriates some form of these conceptions, "new methodologies are necessary, as they contribute to the development of intellectual autonomy, enabling the student to search for knowledge that will help them in solving problems. The active methodologies present themselves as important experiences, because they propitiate moments that stimulate the student in the knowledge's search, in the social life, in the interpretation of roles, making the social actors favorable to the understanding that he is an integral subject of the society and actor of the same, not just spectator" 2 .

The active methodology proposes a more autonomous view of the learner that meets the one proposed by Paulo Freire, a liberating education. In an integrative review "the development of student autonomy, the break with the traditional model, teamwork, the integration between theory and practice, the development of a critical view of the reality and the favor of a formative evaluation"13.

When we refer to the theory of meaningful learning proposed by Ausubell, and remember that the knowledge anchoring system is extremely relevant to learning process, we realize that each subject in its singularity needs to be captured and respected in its diversity in this process: When the learner is able to assign meaning to what is being passed on by the teacher, we say that a meaningful learning is taking place, but these meanings are always influenced by personal attributes. In this way, an apprenticeship is only considered meaningful when there is an attribution of personal meanings and a relation with the students previous knowledge, as well as of his teacher ${ }^{14}$.

In the midst of this quest for the gathering of knowledge, we realize that subjectivity itself is not abdicated. And that it is a form of education far from the neutrality that seeks the citizenship of the student in its most diverse aspects. Damasio and Peduzzi (2015) states that "effectively, scientific education can and should provide relevant subsidies for students to develop a more conscious and active citizenship by promoting a better understanding of the nature of science and the construction of scientific knowledge ${ }^{\text {"15 }}$.

Kolb apud Krakauer (2017) points out that "learning requires opposing skills, and there are two basic dimensions to the learning process. The first represents concrete experience and abstract 
conceptualization. The second dimension refers to active experimentation and reflexive observation, and the learner in such a process often acts as an actor and sometimes as an observer $" 16$.

When we think of Aubusel and his theory "it is important to point out that, for the author, there is no opposition between mechanical and meaningful learning, since he understands them as a continuous process, in other words, in the case of new concepts to the learner, mechanical learning may be ways in which later become significant. Learning may have more meaning; for the student depending on the relationship between the new concept and its cognitive structure, allowing, the individual to discover meanings from their previous knowledge, which is unique. In such process, the new concept interacts with the specific knowledge structure that the individual already possesses called a subsumption" ${ }^{\prime 7}$.

Once again, we must remember that such knowledge is built not in a sealed manner. The constructivist spiral theory which is an active problem-based learning proposes six movements. "Of the six movements of the EC, only search is performed individually. The others are developed in small group meetings with eight to ten learners and a learning facilitator, who must establish a set of rules for collective work. In the interim synthesis, processing begins in the interaction of learners with the learning trigger. The triggers can be: (1) problem situations elaborated by teachers, (2)narratives of practice elaborated by the students, (3) products systematized from the students' performance by means of real or simulated scenarios. This diversity allows us to work the learning teaching process from different perspectives, besides employing a spectrum that includes: (1) more structured and controlled situations, such as problem situations; (2) semi-structured situations, such as simulations; and (3) little controlled situations, such as narratives or products elaborated from acting in real scenarios $" 18$.

Within the active methodologies we still have the PJBL (project-based learning), which was the theoretical approach that grounded the action in this activity with the students. This tool promotes the development of different learner skills during the process. Vasconcelos and Francisco (2015), in a participatory research work, show us that "the methodology of learning through projects, used in the work's developments, provided various manifestations of skills such as: search and research information, problem solving, designing and strategizing, teamwork, interacting with the public and others. This highlights the possibilities and potential of this methodology, demonstrating that work through projects is a promising path to accomplish the learning process" $" 19$.

We know that the great role of he University is to collaborate in the transformation of society. Nevertheless, the university has a very great responsibility that would be a real approximation with the basic education, for teachers training and development of real projects with the secondary students. Currently, our country suffers from a great chasm between higher education and elementary/middle school since excellent projects developed at the academy cannot be "applied" in real life. The basic school is urging for help to modify its curricula, making teaching more meaningful in a globalized and ever-changing world. In this sense, we see the university as a "light at the end of the tunnel" for the rescue of a differentiated education through university-school integration, with projects, capacities and methodologies that allow a meaning to the contents ${ }^{20}$.

This is a concern that has increasingly promoted discussions about the effectiveness of University activities, about the quality of teaching, both in schools, on the centralization and bureaucratization of educational management processes, among, other aspects ${ }^{21,22}$.

Actions are verified that try to corroborate with an improvement in the teachinglearning processes through the support of universities and research centers with the basic education, stimulating the students' interest in the continuity of the studies, also defining careers. But they are still very isolated facts, not being a practice ${ }^{23,24}$.

On the other hand, with a pedagogical proposal to encourage research, Jaguar Land 
Rover has been performing for more than a decade what should be a constant practice of the University, an education program that promotes the revelation of young talents in basic education beyond promoting entrepreneurship, integrating knowledge focused on the current market.

\section{The competition}

For more than twelve years, Jaguar Land Rover annually has promoted a technology competition for high school students, between 14 and 19 years, from different countries, called "4x4 in Schools Technology Challenge". The Technology Challenge is an educational program that aims to insert in the high school a project that is capable of developing skills related to entrepreneurship during its execution, promoting significant changes in the education. The competition has as a proposal to prepare people to learn how to act and think on their own, with creativity, with leadership and vision of the future, to innovate and occupy their space in the market, transforming this act also into emotion and satisfaction.

The $4 \times 4$ in Schools Technology Challenge proposal is based, precisely, on this active student-centered methodology as a way of teaching. Each team receives a chassis of a fourwheel-drive $(4 \mathrm{x} 4)$ miniature vehicle about $20 \mathrm{~cm}$ long, $10 \mathrm{~cm}$ wide and $10 \mathrm{~cm}$ high, and must make adjustments to the mechanical and electrical part of the prototype for the competition. The project consists of each team being a microenterprise, having as a final product the miniature car. The teams need to create a logo and a brand to the product; to seek sponsorship for the development of the prototype; to set up a booth to present the development and research of the vehicle together with information pertinent to the work; publicize sponsors and contributors to social networks by developing a website about the team; analyze, research and execute the construction of bodywork and application of some sensors to the prototype; draw up a portfolio of the entire project from the initial moment until the final execution of the entire study. On a specific day, the teams gather for the exhibition of the entire project in booths and various presentations (talk about Engineering, Marketing, Portfolio). A part of the team's score is defined by the performance of the miniature in time-lapse tests on various obstacles (bridges, tunnels, uneven terrain, etc.)

\section{Objetives}

The main objective of the project was the technological contribution necessary for the participation of students from the Escola Estadual Ciep 291- Dom Martinho Schlude, from Pinheiral, state of Rio de Janeiro, in the $4 \times 4$ in schools competition. As specific objectives, the students of the Centro Universitário de Volta Redonda (UniFOA) should be responsible for developing technical monitoring in relation to: Arduino programming, 3D modeling in Fusion 360, notions of website construction using HTML, creation of a media plan for insertion in social networks and providing general knowledge of automotive mechanics. The purpose of Jaguar Land Rover is to prepare students for issues related to the job market by providing academics and students with notions of Planning, Management, Budget, Teamwork, Marketing and Engineering. Thereby, a project of scientific initiation was developed in the University, captaining students of the courses of Design, Advertising and Marketing, Mechanical Engineering, Electrical Engineering and Information Systems that would be the tutors in the process of teaching/learning.

\section{Project Methodology}


Due to the demands of the competition, CIEP 291- Dom Martinho Schlude, in Pinheiral, RJ, began a partnership with the Centro Universitário de Volta Redonda (UniFOA) and Companhia Siderúrgica Nacional (CSN) to assist the development of the project. After the partnership's approval, a period of discussion began with all those involved on the needs imposed by the Competition $4 \mathrm{x} 4$ in Schools (types of sensors that should be installed, information that should be included on the website, construction of the body using PLA, media for insertion of information on social networks, among others).

The project had the participation of a large group of people, among them, five University professors (one professor of the Information Systems course, two teachers from the course of Electrical Engineering, one professor of the course of Design and one professor from the course of Advertising and Marketing), eleven University students of the course of Information Systems, two students of the course of Electrical Engineering, one student of the course of Mechanical Engineering, five students of the course of Advertising and Propaganda and one student of the course of Design, six students of CIEP 291 (two students of the 1st year of high school, two students of the 2nd year of high school and a student of the 3rd year of high school), two professors of CIEP291, three Engineers and four Electrical Technicians of Companhia Siderúrgica Nacional. This stage lasted for a month and was held in the school, taking place on Saturdays with the presence of all participants, separated by related areas, until the mapping of all real needs for the Team. All the requirements of the regulation were listed and the working groups separated for each demand.

The first requirement of the Team was the elaboration of a logo and a visual identity for the uniform, stands and portfolio. Facing this task, it was agreed that the secondary students would be assisted by the students of the course of Advertising and Marketing.

As the high school did not have any vocational courses in the area, a second-year student in the UniFOA Information Systems course was recruited to give full support in the development of the site. A work plan was created for the student, linked to a project of scientific initiation for the monitoring and assistance in the construction.

Following the proposal above, the students of the Electrical Engineering course contributed for the elaboration of the sensors. Two students, one from the eighth period and the other from the sixth period, were selected, all with expertise in Arduino programming to transmit knowledge. They gave classes at the school to the two AUTO291 members responsible for prototype Engineering.

For the design of the body, it would have to be developed a project in Fusion 360. A student of the Information Systems course, which had been enabled by Autodesk, was the student responsible for instructing the secondary students. There was also a requirement to define the correct material for printing that could have less aggression to the environment, less cost, good performance and ease of handling. It was agreed among all that the body would be printed using PLA, (polylactic acid, a biodegradable thermoplastic derived from renewable sources like corn starch, cassava and cane roots), being the most environmentally correct option.

For mechanical studies of the project, was selected a tenth period student of the course of Mechanical Engineering that had as a function to analyze the possibility of changes in the prototype provided by Land Rover. He also developed technical monitoring for automotive mechanics.

Knowing what had to be developed, the UniFOA students, together with the supervisors, began the second stage where they set up a work schedule for technical monitoring, separated by specific themes in order to provide relevant information to the development of the project. In this stage, UniFOA students were the tutors in the learning process, teaching five different workshops: notions of Fusion360 (autodesk), notions of making websites using 
HTML, notions of media plans, notions of automotive mechanics, notions of programming in Arduino. This part of the project lasted for two months with the studies being carried out at CIEP 291, and also UniFOA, with the help of CSN Technicians and Engineers. The meetings lasted for two hours a week. In the next stage, the needs that the project demanded simultaneously began to be solved, since each secondary student had a certain role in the team (Marketing Manager, Mechanical Engineer, Electrical Engineer, Project Engineer, Graphic Designer and General Manager).

\section{Results}

The AUTO291 Team, with the support of UniFOA's students and CSN professionals, was able to develop all the requirements defined by the regulation in order to participate in the Competition. Below is the result after six months of work, starting in May and ending in November 2017.

Below is the brand defined for the AUTO291 Team. It was decided as an allusion to CIEP 291 and because it is a microenterprise of the automobile sector among the UniFOA students and members of the school. The format of the stand, portfolio and uniform for the Team were also defined, as shown in the Figure 1, Photograph 1 and Photograph 2.

\section{BRAND \\ CONSTRUCTION}

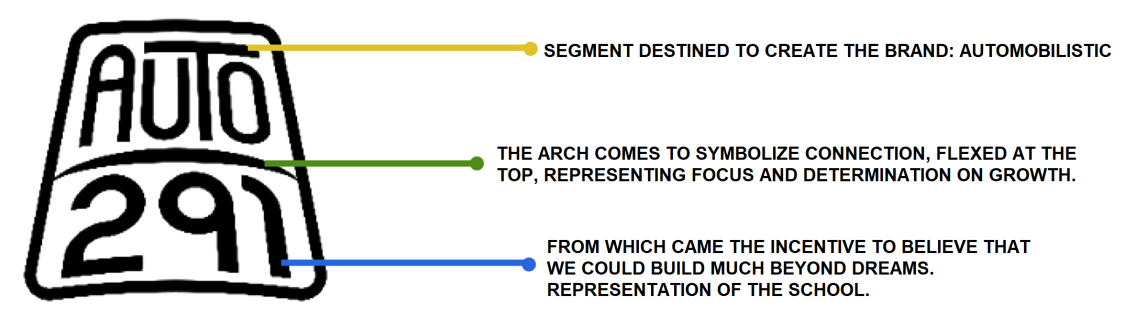

Figure 1. Logo developed by the students for the Auto291 Team. 


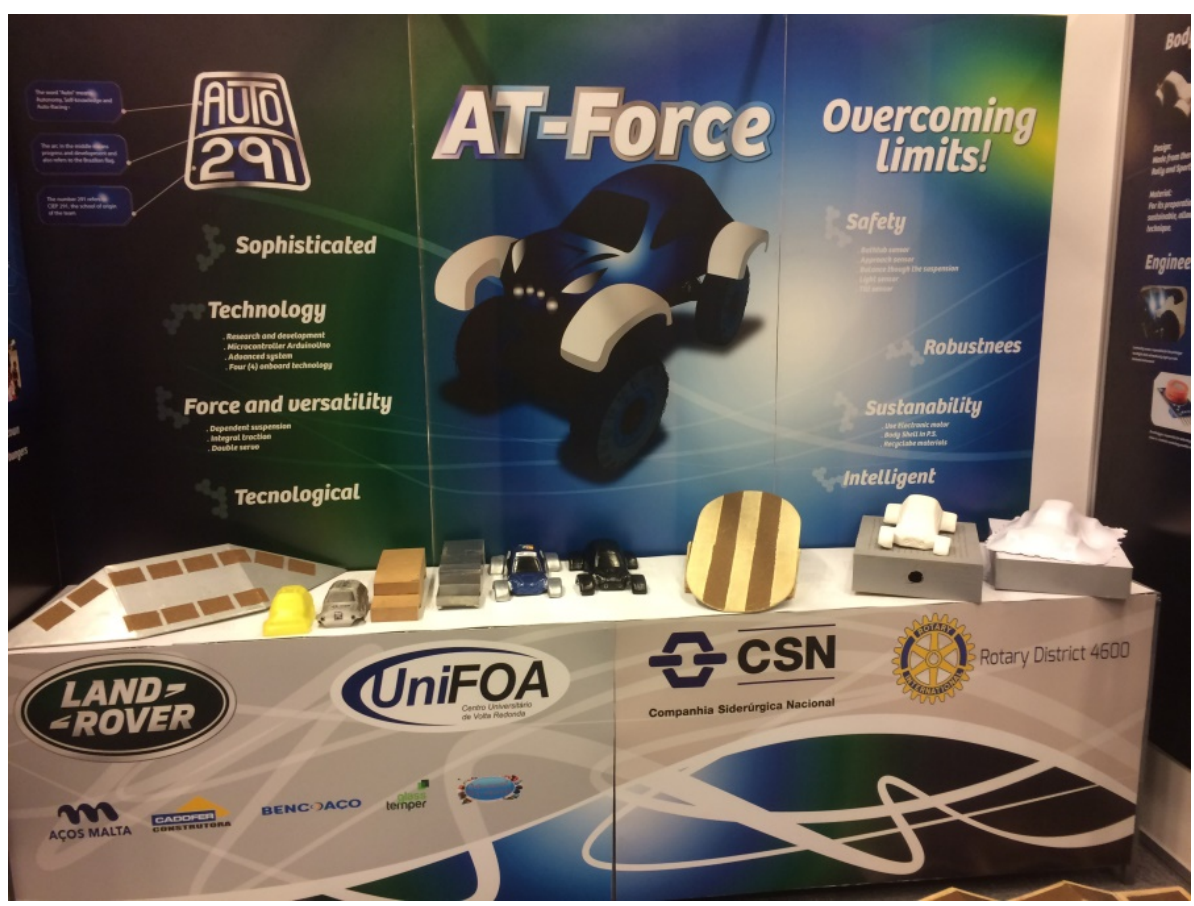

Photograph 1. Stand set for competition.

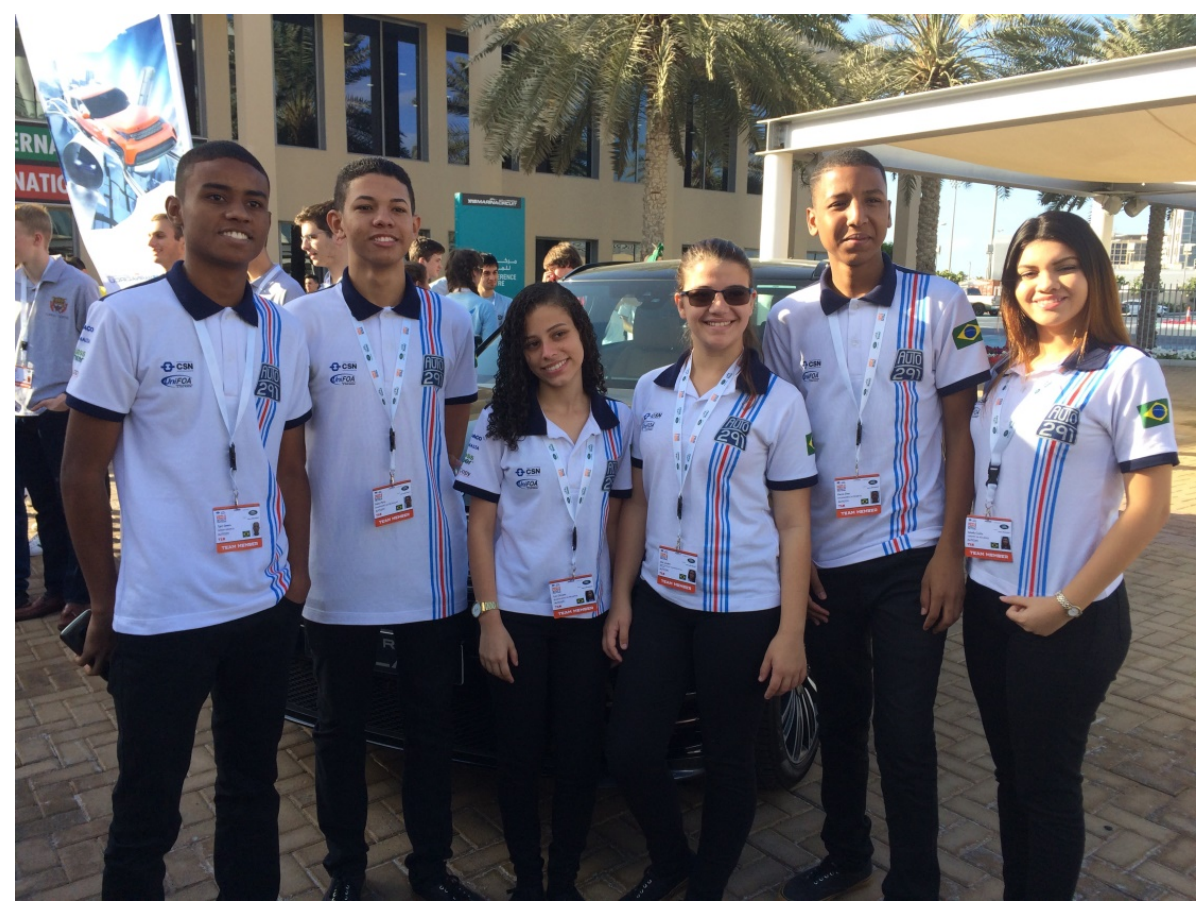

Photograph 2. Visual identity of the members of AUTO291 Team. 
The social media were created to publicize the sponsors and actions developed and with the support of the students of the course of Advertising and Propaganda. Media plans were created for daily insertion of content related to the project. The Figure 2 referring to the team website and social networks.

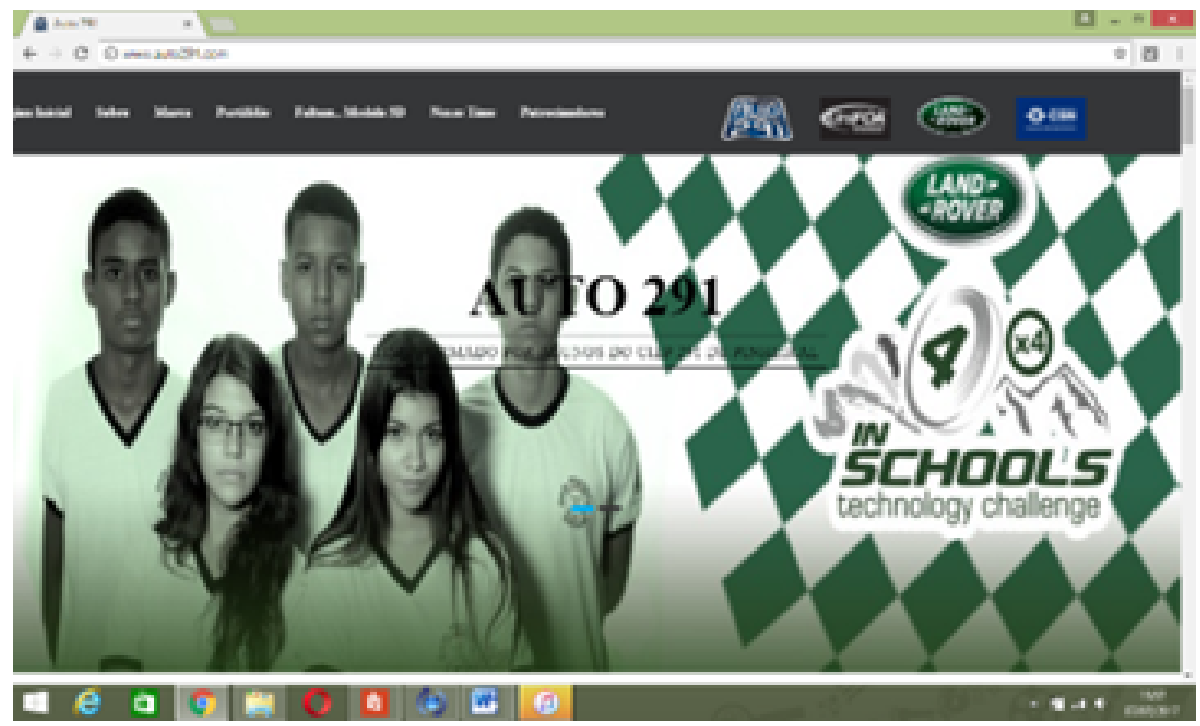

Figure 2. Website developed in HTML for sponsors and actions disclosure.

The 3D drawings were made in Autodesk Fusion 360, in the computer lab of UniFOA, those that participated were University students and secondary students, with the outcome managed to be finalized within two months. XYZ Printing 1.0 Pro was printed at the Technological Innovation Laboratory of UniFOA, campus Três Poços, Volta Redonda, RJ, as shown in Figures 3 and 4.

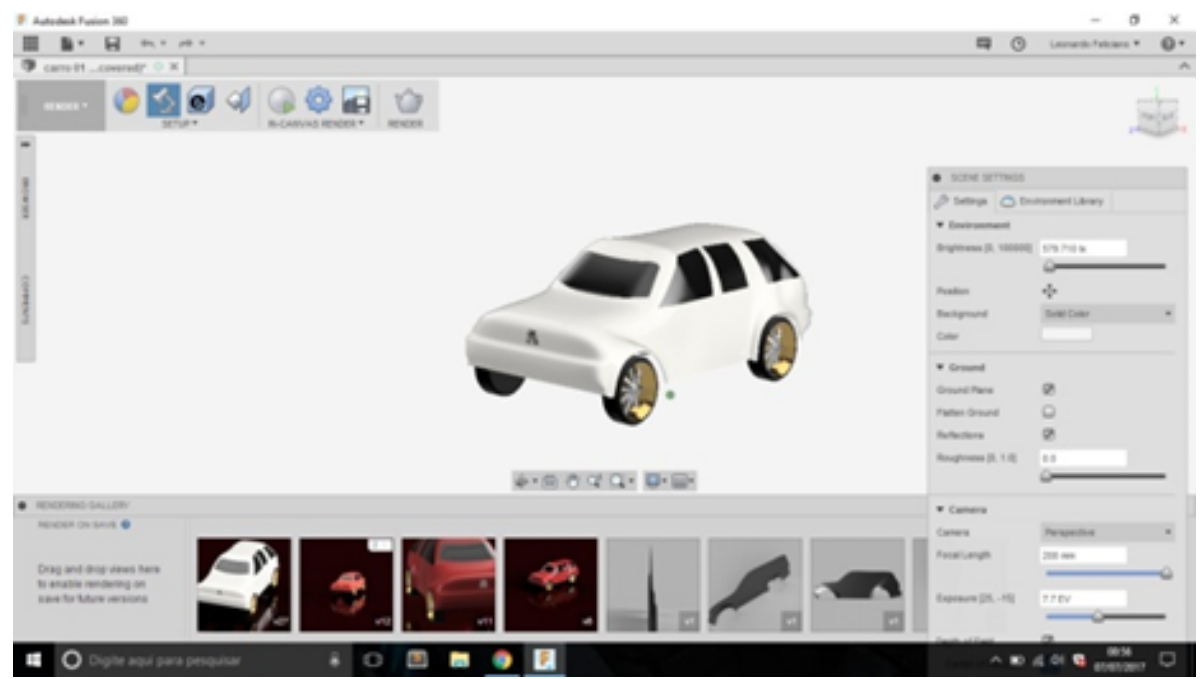

Figure 3. 3D prototype drawing. 


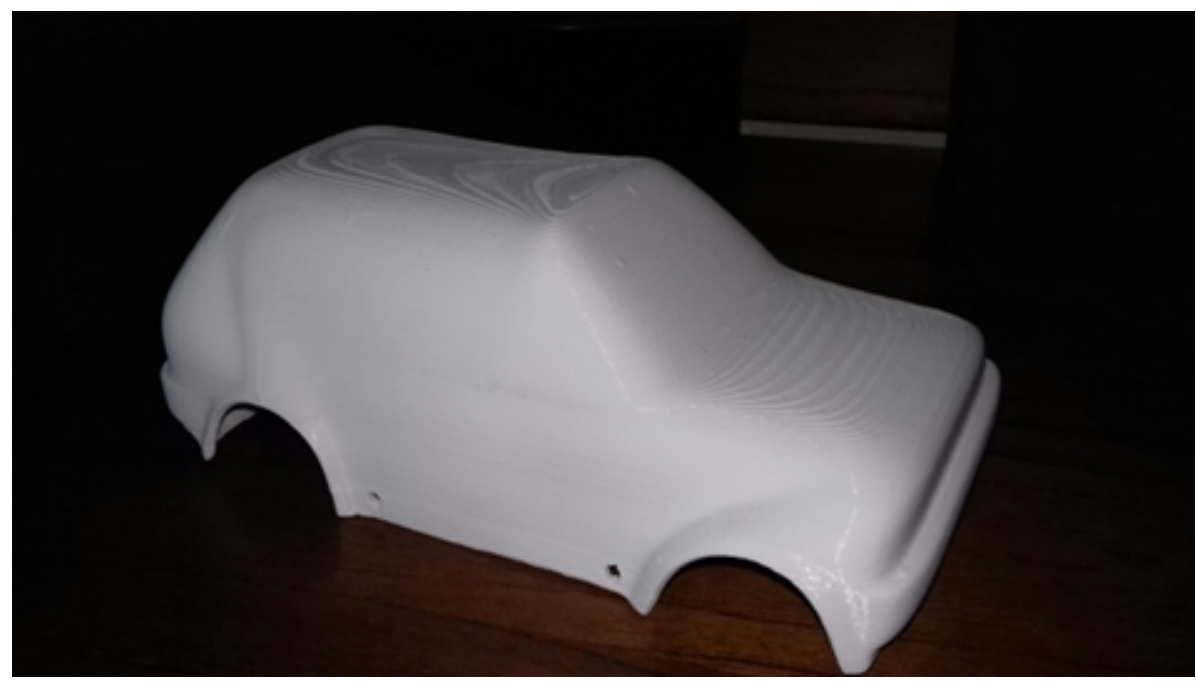

Figure 4. Body after printing.

For the competition were installed the mandatory sensors for the regulation that are those of luminosity (when entering an environment with low light it triggers), and of inclination (when passing through an obstacle with a slope greater or equal to $25^{\circ}$ with the horizontal it beeps). Approximation sensors were also installed in the rear (when approaching the prototype of an obstacle it triggers a sound signal), and headlights in led. The Team also managed to develop a sensor to check the alcohol content among drivers, called a breathalyzer. The mounted sensors are shown in the Photographs 3 and 4, and the settings for operation are shown in Frames 1, 2, 3 and 4.

Frame 1. Lighting lights.

IDENTIFICATION OF DOORS AND COMMANDS
$/ /$ Creates constants with the names and pins of the outputs (LED pin and buzzer)
const byte LED $=13 ; / /$ Headlight
const byte LED1 $=12 ; / /$ Headlight
const byte LED2 $=9 ; / /$ Taillight
const byte LED3 $=8 ; / /$ Taillight
const byte LED $=10 ; / /$ Reversing lights
const byte LED5 $=11 ; / /$ Reversing lights
const byte LED6 $=4 ; / /$ Down light
const byte LED7 $=3 ; / /$ Down light
const byte BUZ $=7 ; / /$ BUZZER
PIN SETTINGS AS OUT OF INFORMATION
$/ /$ sets pins as output (OUTPUT)
pinMode(LED, OUTPUT);
pinMode(LED1, OUTPUT);
pinMode(LED2, OUTPUT);
pinMode(LED3, OUTPUT);
pinMode(LED4, OUTPUT);
pinMode(LED5, OUTPUT);


pinMode(LED6, OUTPUT);

pinMode(LED7, OUTPUT);

pinMode(BUZ, OUTPUT);

Frame 2. Brightness sensors.

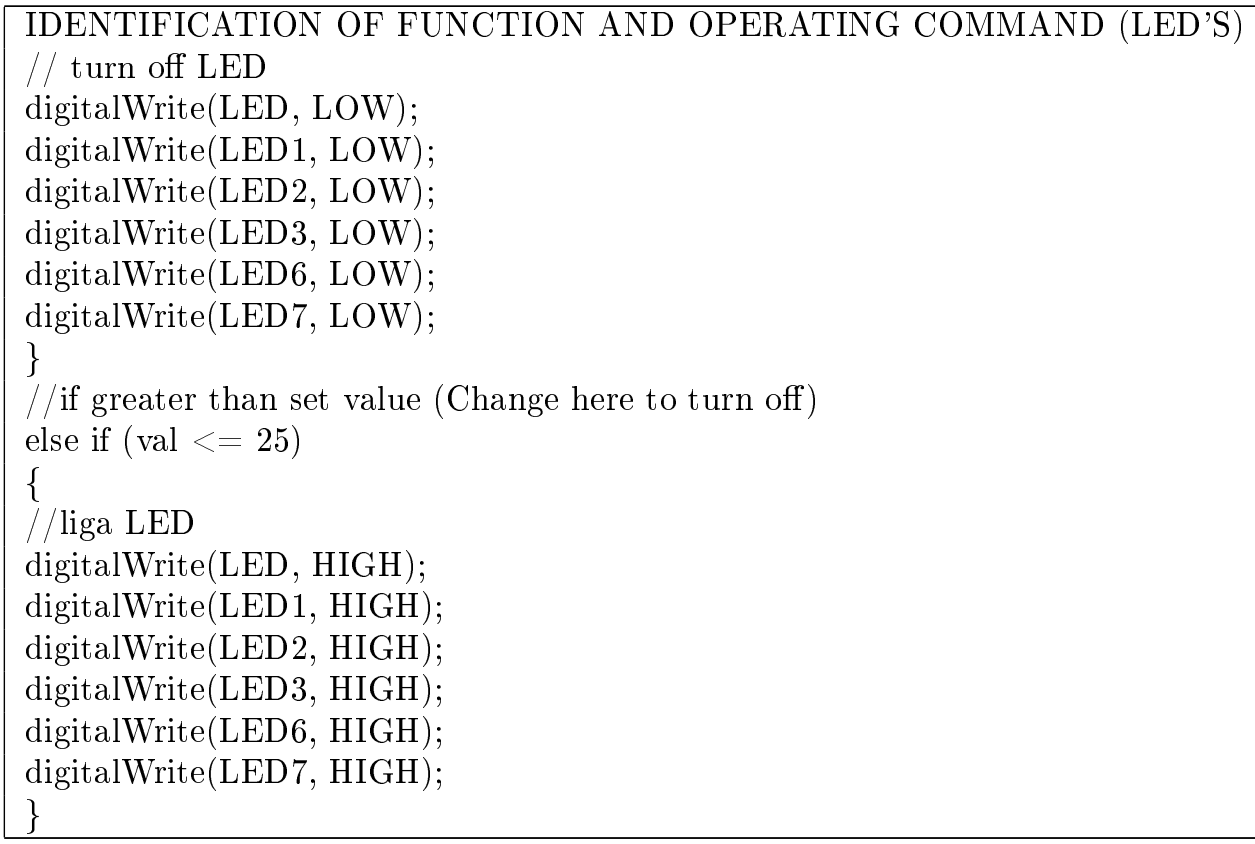

Frame 3. Approach sensors.

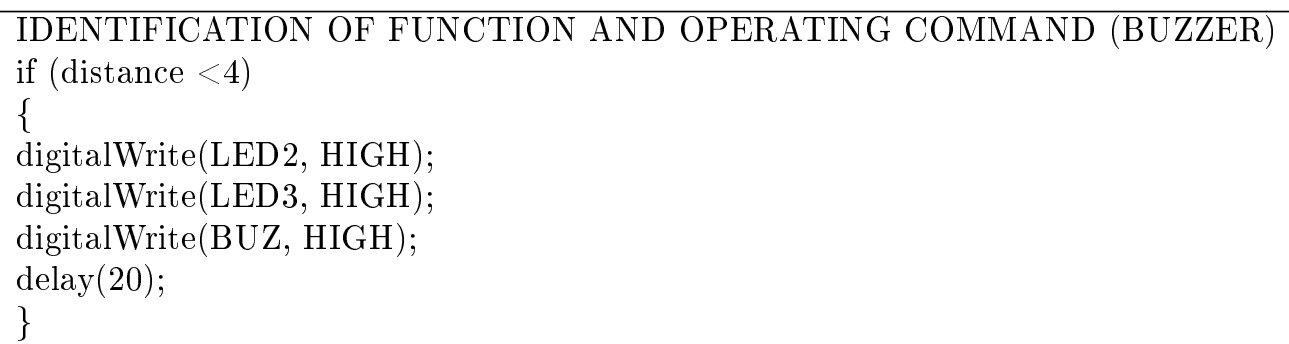


Frame 4. Tilt sensors.

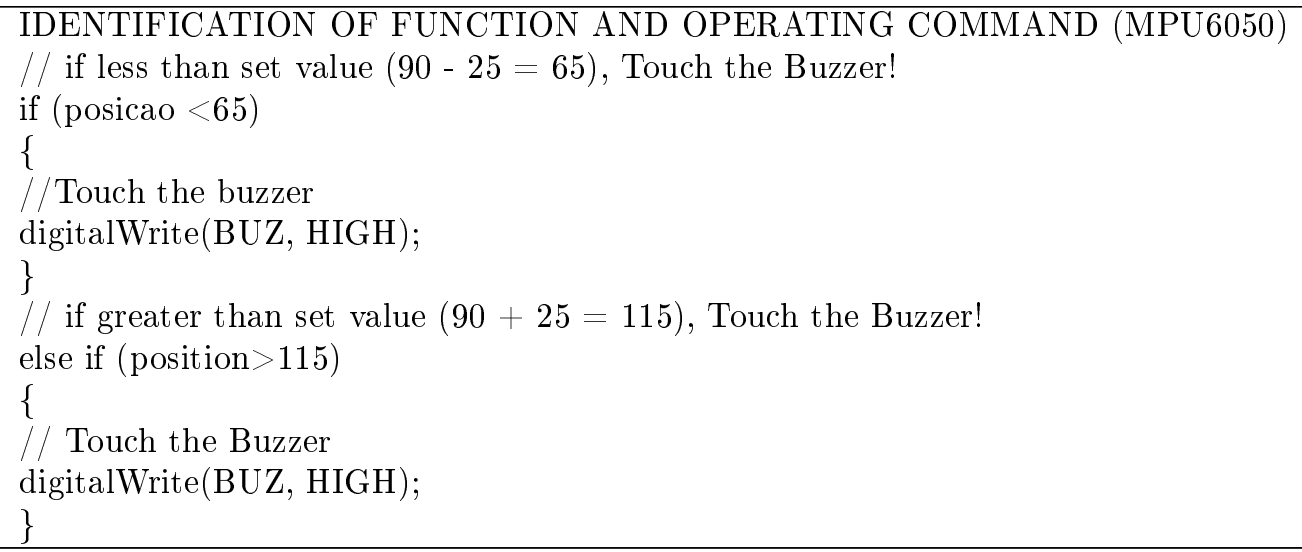

The sensors were installed in the prototype shown in the Photograph 5.

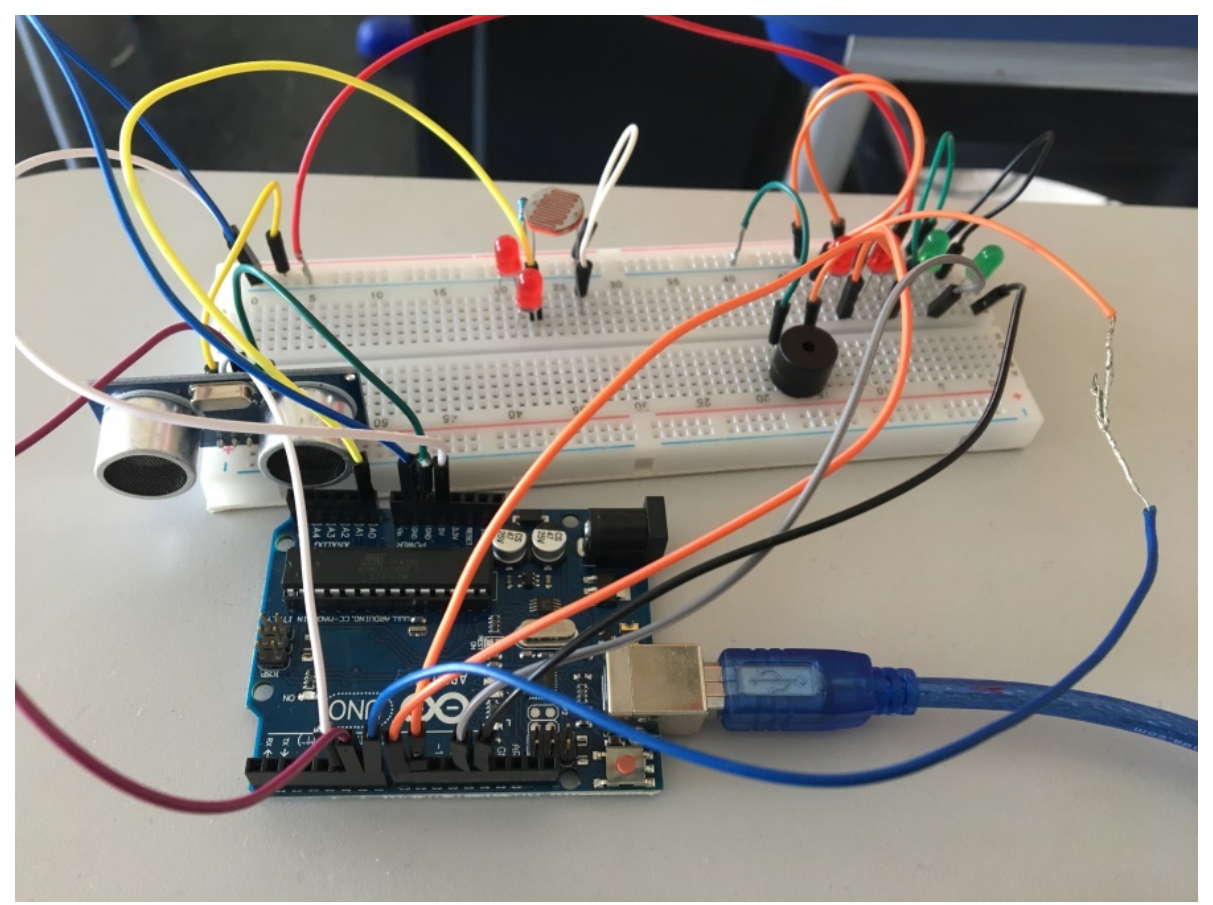

Photograph 3. Light sensor for prototype. 


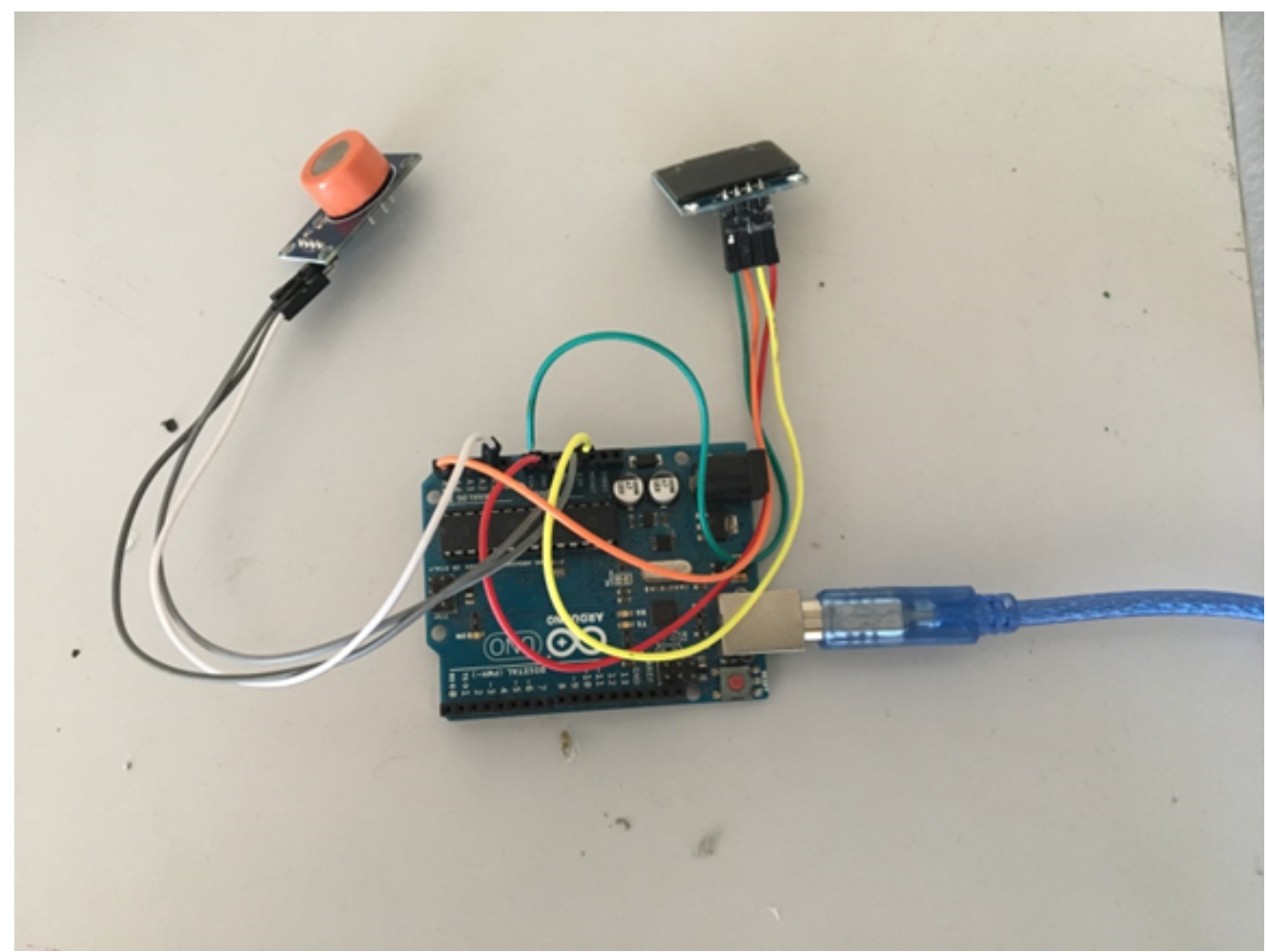

Photograph 4. Breathalyzer for prototype.

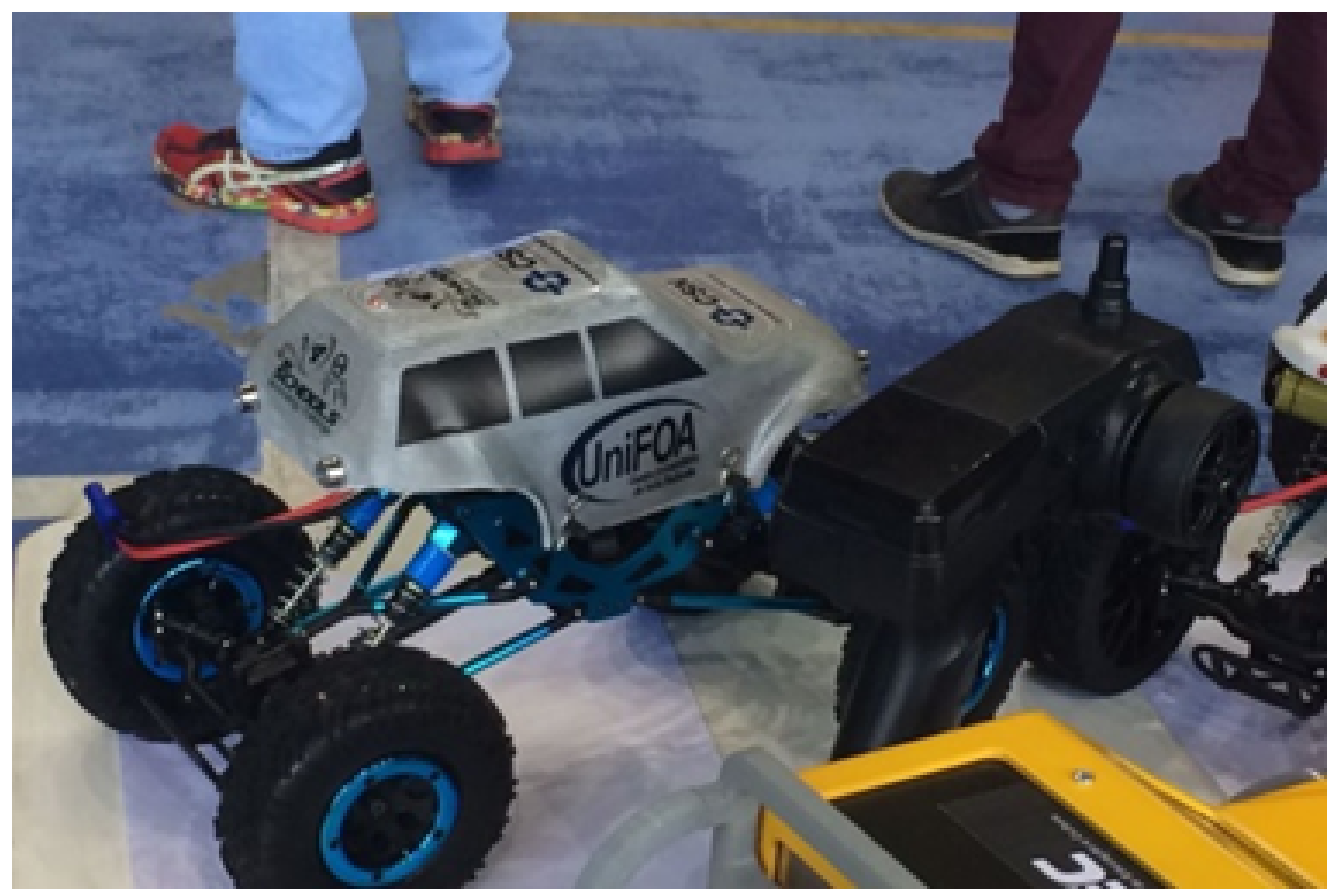

Photograph 5. Trolley mounted with body and installed sensors. 
The performance of AUTO291 was exceptional during the competition, with the presence of eight high schools in Rio Fluminense, Rio de Janeiro and the city of Campinas, SP. They were the first-time national champions (they competed with five schools) and won three individual prizes (better Engineering, better verbal presentation and better female participation) of the five in contention. We believe that a new concept of the world and the job market has been instilled in CIEP 291 youth, who participated in the $4 \times 4$ in Schools Project. UniFOA's students, who provided consulting services to the Team, giving technical support, learned to prepare for inclusion in the job market, where they will have to develop business management skills and have mastered the University's role in Society, which is to reproduce knowledge by arousing interest in the study by being able to solve and deal real-life problems.

\section{Conclusions}

The greatest difficulty encountered for the development of the project was the excess of requirements to be fulfilled in a short period of time. Facing such difficulties, as the lack of support in the Public education in the State of Rio de Janeiro that has been abandoned by the authorities over the years, not giving equal conditions with private education for educational professionals to perform their services with mastery. Thereby, in this network of facts, we also perceive a student's profile with no ideal conditions to search for knowledge and with great lack of stimulation in learning. Adding to all this the lack of investments in technology in schools for the development of scientific and didactic works, we can say that this project appeared as an excellent alternative to try to do something different than what is proclaimed in the state schools of Rio de Janeiro.

With this intention, to show that it is possible to carry out projects with quality, even in peripheral schools, Ciep291 teachers in Pinheiral began this journey. However, in the pedagogical part, the secondary students found problems in almost all the questions proposed exactly due to lack of technical knowledge. It is not easy to teach programming, marketing actions, site creation among other demands for 15 and 16 years olds who have never had access to this information in four to six months. As Ciep 291 students, they have a full-time program, so the technical supervision of University students had to take place in the evenings and on weekends. A work plan was created within the possibilities of execution and almost all deadlines were not accomplished, however they managed to finish what had been proposed for the competition.

At the University level, we perceive the difficulty of the student of Information Systems in teaching how to make the site in HTML. In this case, a student who was not part of the project, from a period above, was recruited to convey information in order to teach how to do it. It was also noticed that the Electrical Engineering students had difficulties in providing technical monitoring for the inclination sensors in the miniature body. At this moment the advisors had technical assistance from CSN Engineers and Technicians who were responsible for all support and information, both for college students and for high school students.

In $3 \mathrm{D}$ printing the initial design that had been made had the specifications smaller than the one proposed by the regulation. With that, the body had to be remade with the correct dimensions and this also generated a certain discomfort with the time in which the students had available. Regarding the mechanical changes, the student of Mechanical Engineering realized that for the short time available, it would be very difficult to develop another chassis and parts for the prototype. With that, in the mechanical part the car could not undergo any significant change keeping the same chassis, suspension and engine of the model delivered by Land Rover for the competition. 


\section{Acknowledgment}

In this topic, the authors are pleased to thank all Auto291 staff, in particular: FOA/ UniFOA, CSN, Prefeitura de Pinheiral and Ciep291 teachers and students who collaborated intensely in production of this project.

\section{Reference}

1. LUCKESI, C. C. Filosofia da Educação. São Paulo: Cortes, 1994.

2. REGO, T. C. Vygotsky: uma perspectiva histórico-cultural da educação. Petrópolis: Vozes, 1995.

3. DIAS, R. F. N. C.; BUENO, F.F.L. O processo ensino aprendizagem na perspectiva da teoria histórico-cultural de Lev Vygotsky. Revista Triângulo, v. 8, n. 2, p. 172-184, 2015.

4. SANTOS, R.; SILVA, A. F. Teorias pedagógicas que tratam da questão educacional com ênfase nos seus aspectos psicológicos e socioeducativos e sua necessidade para a compreensão das indicações da Unesco para a educação no século XXI. Caderno de Relações Internacionais, v. 8, n. 14, p. 315-318, 2017.

5. DIESEL, A.; BALDEZ, A. L. S. Os princípios das metodologias ativas de ensino: uma abordagem teórica Active teaching methodologies principles: a theoretical approach. Revista Thema, v. 14, n. 1 , p. $268-288,2017$.

6. FREIRE, P. Pedagogia da Autonomia: saberes necessários à prática educativa. São Paulo: Paz e Terra, 1996.

7. MENDONÇA, S.; ADAID, F. A. P. Experiência e educação no pensamento educacional de John Dewey: Teoria e prática em análise. Prometeus, n. 25, 2018.

8. BARBOSA, R. G.; BATISTA, I. L. Vygotsky: Um Referencial para Analisar a Aprendizagem e a Criatividade no Ensino da Física. Revista Brasileira de Pesquisa em Educação em Ciências, p. $49-67,2018$.

9. FARIAS, I. M. S.; SAlES, J. O. C. B.; BRAGA, M. M. S. C.; FRANÇA, M. S. L. M. Didática e docência: aprendendo a profissão. Editora Brasília, Liber Livro, 2014.

10. VYGOTSKY, L. Pensamento e Linguagem. São Paulo: Editora Martins Fontes, 1987.

11. BORGES, T. S.; ALENCAR, G. Metodologias ativas na promoção da formação crítica do estudante: o uso das metodologias ativas como recurso didático na formação crítica do estudante do ensino superior. Cairu em Revista, n. 4, p. 119-143, 2014.

12. TEIXEIRA, L. A. A.; HILGBERT, I. M. P. Metodologias ativas e o desenvolvimento da autonomia intelectual. Revista Thema, v. 7, n. 2, p. 1-10, 2017.

13. PAIVA, M. R. F.; PARENTE, J. R. F. P.; BRANDÃO, I. R.; QUEIROZ, A. H. B. Metodologias ativas de ensino aprendizagem: uma revisão integrativa. Revista de Políticas Públicas, v. 15, n. 2, p. 145-153, 2016.

14. JUNIOR, R. S. S. Um olhar diferenciado para a aprendizagem significativa ao aluno. Caderno de Fisica da UEFS, v. 12, n. 2, p. 07-10, 2014.

15. DAMASIO, F.; PEDUZZI, L. O. Q. A coerência e complementaridade entre a teoria da aprendizagem significativa crítica e a epistemiologia de Paul Feyerabend. Investigações em Ensino de Ciências, v. 20, n. 3, p. 61-83.

16. KRAKAUER, P. V. C.; SANTOS, S. A.; ALMEIDA, M. I. R. Teoria da aprendizagem experiencial no ensino de empreendedorismo: Um estudo exploratório. Revista de Empreendedorismo e Gestão de Pequenas Empresas, v. 6, n. 1.

17. DISTLER, R. R. Contribuições de David Ausubel para a intervenção psicopedagógica. Revista Psicopedagogia, v. 32, n. 98, p. 191-199, 2015.

18. LIMA, V. V. Espiral construtivista: uma metodologia ativa de ensino-aprendizagem. Comunicação Saúde Educação, v.21, n. 61, p. 421-434, 2017.

19. VASCONCELOS, M. H.; FRANCISCO, W. Feira de ciências e ensino por projetos: uma experiência educativa no norte do Brasil. Revista de Ensino de Ciências e Matemática, v. 17, n. 1, p. $235-251$. 
20. PEREIRA, T. R. D. S.; NASCIMENTO F. S.; PEREIRA, I. B.; ANJOS, T. D. S. Potencial social de articulação entre ensino médio e a engenharia articulação universidade e ensino médio: as potencialidades das geotecnologias e o conhecimento científico na escola. Revista Dynamis, v. 2, n. 12, p. 29-35, 2012.

21. TAUCHEN, G.; DEVECHI, C. P. V.; TREVISAN A. L. Integração Universidade e Escola: uma colaboração entre ações e discursos. Revista Dialogo e Educação, v. 14, n. 42, p. 369-393, 2014.

22. KOLLN, A. D.; GOMES, M. F. V. B. Projetos de extensão na busca pela integração entre universidade e escola. Available in: $<$ http://observatoriogeograficoamericalatina.org.mx/egal12/Ensenanzadelageografia/Desempe noprofesional/12.pdf $>$. Accessed on: 30 May 2017.

23. MACHADO, M. A. D.; QUEIROZ, G. R. P. C. Cultura de Projetos, construída via Parceria Escola-Universidade, contribuindo para a qualidade da formação inicial e continuada de professores. Revista Brasileira de pesquisa na Educação em Ciências, v. 1, n. 12, p. 93-116, 2002.

24. MARINS, L. A.; GOUVEIA, F. C.; SOARES, D. C.; VIEIRA, C. E. C.; VENTURELli, E. Project Based Learning: The Integration of Knowledge, Skills and Attitudes through The 4x4 In Schools Challenge. In: INTERNATIONAL CONFERENCE ON ALIVE ENGINNERING EDUCATION, 2018, Puerto Iguazú. Electronic Proceedings... Goiânia: Gráfica UFG, 2018. p. 116117. Available in: <https://icaeedu.emc.ufg.br/p/27041-icaeedu-2018-publications $>$. Accessed on: 12 Mar. 2019.

25. MARINS, L. A. et al. Project Based Learning: The Integration of Knowledge, Skills and Attitudes through The $4 \times 4$ in Schools Challenge. In: DEUS JUNIOR, G. A. de et. al. (Org.). Alive Engineering Education: Integrating and Innovating Engineering Education in Favor of Society. Goiânia: Gráfica UFG, 2019. cap. 54, p. 555-564. Available in: $<$ https://icaeedu.emc.ufg.br/p/27041-icaeedu-2018-publications >. Accessed on: 29 May 2019. 
